\section{Loyalitas Kreativitas \\ Aldi Masyarakat Kreatif}

P-ISSN 2722-2101, E-ISSN 2722-4201

Program Studi Ekonomi Manajemen Universitas Pamulang Jurnal LOKABMAS Kreatif Vol. 01, No. 03, Hal. 44-52

Email:jurnalkreatif.manajemen@gmail.com

\title{
PELATIHAN UNTUK PARA PELAKU UMKM AGAR BERTAHAN MENGHADAPI KRISIS AKIBAT PANDEMI COVID-19 WARGA PERIGI, PONDOK AREN, TANGERANG SELATAN
}

\author{
Wahyu Nurul Faroh, Muhamad Restu Wijaya, Budi Syamtoro, \\ Ratnawati, Sri Eka Lestari \\ Dosen Ekonomi Fakultas Ekonomi Universitas Pamulang \\ Mahasiswa Program Studi Manajemen Universitas Pamulang \\ Email: dosen01061@unpam.ac.id, dosen02268@unpam.ac.id, \\ dosen02332@unpam.ac.id, dosen00072@unpam.ac.id, \\ dosen00524@unpam.ac.id,
}

\begin{abstract}
ABSTRAK
Semakin meningkatnya penyebaran virus Corona atau yang sering disebut dengan Covid-19 menghambat aktivitas masyarakat di luar rumah. Sehingga secara langsung maupun tidak langsung menyebabkan perlambatan dan kelumpuhan ekonomi. Hal ini tentunya berdampak besar untuk warga yang kesehariannya sebagai pedagang, pekerja di sektor informal seperti tukang bangunan, tukang ojek, guru ngaji honorer, dsb. Mereka ini adalah masyarakat yang penghasilannya didapatkan dengan cara bertemu langsung dengan para konsumen atau kliennya.

Dalam kegiatan Pengabdian Kepada Masyarakat kami melakukan kerjasama dengan Warga Kampung Parigi Rt.003/005 kelurahan Parigi Kecamatan Pondok Aren Tangerang Selatan. Dari hasil survey dan wawancara melalui Warga Kampung Parigi Rt.003/005 bahwa permasalahan yang ada sekarang ini dan masih berlanjut salah satunya yaitu para pelaku UMKM utamanya pedagang kecil yang berada di daerah perkampungan pondok aren tidak mendapatkan penghasilan, dikarenakan tidak bisa keluar rumah untuk menjual barang dagangannya secara langsung kepada para konsumen.

Tujuan jangka pendek PKM ini adalah untuk memotivasi para UMKM warga kampung perigi agar percaya diri memasarkan dagangannya,sarana pemasaran yang di gunakan adalah pemasaran online, karena dengan dengan pemasaran online di masa pandemik ini paling efektif, dan tujuan jangka panjang pelatihan ini diharapakan para UMKM warga perigi ini lebih mandiri dan lebih terbiasa dengan pemasaran online ini. metode yang akan dipakai dalam pencapaian tujuan yaitu dengan berbagai metode seperti ceramah, diskusi dan tanya jawab, serta pendampingan bagi masyarakat secara rutin.
\end{abstract}

\section{Kata kunci: Donasi, UMKM, Covid-19, Pelatihan}

\section{ABSTRACT}

The increasing spread of the Corona virus or what is often referred to as Covid-19 is hampering community activities outside the home. So that directly or indirectly it causes economic slowdown and paralysis. This certainly has a big impact on residents who work as traders on a daily basis, workers in the informal sector such as construction workers, motorcycle taxi drivers, honorary teachers, etc. They are people whose income is obtained by meeting directly with consumers or clients.

This Community Service Activities, we collaborated with the residents of Kampung Parigi Rt.003 / 005, Parigi Village, Pondok Aren District, South Tangerang. From the results of surveys and interviews through residents of Kampung Parigi Rt.003 / 005 that the problems that exist today and are still continuing, one of them is that MSME workers, especially small traders who are in the Pondok Aren village area, do not get income, because they cannot leave the house to sell merchandise directly to consumers. 


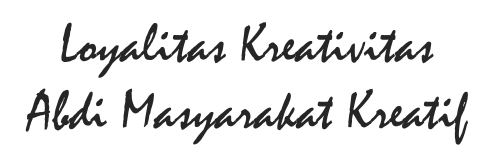

P-ISSN 2722-2101, E-ISSN 2722-4201

Program Studi Ekonomi Manajemen Universitas Pamulang Jurnal LOKABMAS Kreatif Vol. 01, No. 03, Hal. 44-52

Email:jurnalkreatif.manajemen@gmail.com

The short-term goal of this Community Service Activities is to motivate the MSME workers resident of Perigi village to be confident in marketing their wares. The marketing strategy used is online marketing, because with online marketing in this pandemic period is the most effective. And the longterm expected goal of this training is that the MSMEs in Parigi, could be more independent and more familiar with this online marketing. The methods that will be used in achieving the goals are various methods such as lectures, discussions and questions and answers, as well as regular community assistance.

Keywords: Donation, UMKM, Covid-19, Training

\section{PENDAHULUAN}

\subsection{Analisis Situasi Permasalahan}

Virus Corona atau sering disebut dengan Covid-19 merupakan penyakit menular yang disebabkan oleh virus bernama SARS-COV-2. Virus Corona sendiri merupakan keluarga virus yang sangat besar, karena berkerabat dengan virus flu pada umumnya, virus penyebab penyakit Severe Acute Respiratoy Syndrome (SARS), serta penyebab Middle East Respiratory Syndrome (MERS). Ada yang menginveksi hewan, seperti kucing dan anjing, namun ada pula jenis Virus Corona yang menular ke manusia, seperti yang terjadi pada Covid-19. Virus Corona ini merupakan penyakit baru, jadi manusia belum punya kekebalan tubuh terhadap Virus SARS-Cov-2. Vaksin dan obatnyapun belum ditemukan. Saat ini, peneliti di penjuru dunia masih berlombalomba mencari vaksin dan obatnya.

Kurang tanggapnya respon pemerintah Indonesia terhadap virus ini dalam hal sosialisasi dan pencegahan awal, menyebabkan penyebaran virus Covid-19 begitu cepat hingga sudah seluruh provinsi di Indonesia terkena dampaknya. Hal itu ditambah lagi dengan kurangnya kesadaran masyarakat untuk menjaga kesehatan dan kebersihan. Kurangnya sosialisasi Pedoman Pencegahan dan Pengendalian Covid-19 kepada masyarakat, sehingga banyak yang tidak mengetahui bahwa dirinya adalah Orang Dalam Pemantauan (ODP), Pasien dalam Pengawasan (PDP) dan Suspek sehingga mereka merasa sehat dan masih keluar kota dan bahkan keluar negeri. Tanpa disadari bahwa mereka sudah menjadi carrier atau membawa virus Covid-19.

Hal tersebut menyebabkan kenaikan kasus yang terinfeksi Covid-19 menjadi sangat cepat dan masif. Data yang dikeluarkan oleh pemerintah menunjukkan bahwa per tanggal 30 April 20202020 jumlah yang terinfeksi di Indonesia terus meningkat dengan total 10.118 kasus positif. Meninggal akibat virus corona sebanyak 792 orang dan sembuh sebanyak 1522 orang. Sementara untuk seluruh dunia pada tanggal 30 April 2020 dari 3.089.013 kasus positif, sebanyak 217.551 orang telah meninggal dunia. Sementara 888.091 orang dinyatakan telah sembuh dari virus corona ini. Meskipun demikian penyebarannya yang sangat cepat masih menjadi masalah utama. Karena bisa saja orang yang terkena virus ini tidak merasakan dampaknya, akan tetapi mereka bisa menyebarkan kepada orang lain, dan saat ada orang yang sedang lemah imunitas tubuhnya mereka akan langsung terkena penyakit ini.

Hal ini menyebabkan banyak Pemimpin Pemerintah Daerah yang melakukan Lockdown di daerahnya masing-masing untuk mengurangi penularan virus tersebut. Oleh karena itu, Pemerintah Daerah mengajukan Pembatasan Sosial Berskala Besar (PSBB) yang diajukan kepada Menteri Kesehatan yang diatur dalam Undang-Undang No. 6 Tahun 2018 tentang Karantina Kesehatan dan sesuai dengan Keputusan Presiden Republik Indonesia Nomor 11 Tahun 2020 tentang Penetapan Kedaruratan Kesehatan Masyarakat Corona Virus Desease 2019 (Covid-19).

Penyebaran Covid-19 yang bersifat luar biasa dengan ditandai jumlah kasus 


\section{Loyalitas Kreativitas \\ Aldi Masyarakat Kreatif}

P-ISSN 2722-2101, E-ISSN 2722-4201

Program Studi Ekonomi Manajemen Universitas Pamulang Jurnal LOKABMAS Kreatif Vol. 01, No. 03, Hal. 44-52

Email:jurnalkreatif.manajemen@gmail.com dan/atau jumlah kematian telah meningkat dan meluas lintas wilayah dan lintas negara dan berdampak pada aspek politik, ekonomi, sosial, budaya, pertahanan dan keamanan, serta kesejahteraan masyarakat di Indonesia, maka Presiden mengeluarkan Peraturan Pemerintah Republik Indonesia Nomor 21 Tahun 2020, tentang Pembatasan Sosial Berskala Besar Dalam Rangka Percepatan Penanganan Corona Virus Disease 2019 (Covid-19).

Dalam Peraturan Pemerintah tersebut setelah gubernur mengajukan permohonan untuk menerapkan Pembatasan Sosial Berskala Besar. Kementerian Kesehatan akan menerbitkan SK Menkes yang selanjutnya SK ini menjadi landasan hukum penerapan PSBB. Penerapannya adalah per 14 hari, artinya apabila setelah 14 hari belum ada penurunan kasus corona. Maka penerapan PSBB bisa diperpanjang 14 hari lagi dan begitu seterusnya.

Pemerintah Banten mengeluarkan Peraturan Gubernur Nomor 25 tahun 2020 tentang pedoman pelaksanaan Pembatasan Sosial Berskala Besar (PSBB) yang berlaku untuk Kota Tangerang, Kota Tangerang Selatan, dan Kabupaten Tangerang dimulai dari tanggal 14 Juni 2020. Isinya mengatur pembatasan di sektor pendidikan, tempat kerja, fasilitas umum dan ibadah, kegiatan budaya sampai moda transportasi, dan disebut paling akhir ini, termasuk penggunaan kendaraan pribadi, hingga protap angkutan roda dua berbasis online.

Semakin meningkatnya penyebaran virus Corona atau yang sering disebut dengan Covid-19 menghambat aktivitas masyarakat di luar rumah. Sehingga secara langsung maupun tidak langsung menyebabkan perlambatan dan kelumpuhan ekonomi. Hal ini tentunya berdampak besar untuk warga yang kesehariannya sebagai pedagang, pekerja di sektor informal seperti tukang bangunan, tukang ojek, guru ngaji honorer, dsb. Mereka ini adalah masyarakat yang penghasilannya didapatkan dengan cara bertemu langsung dengan para konsumen atau kliennya.

Dalam kegiatan Pengabdian Kepada Masyarakat kami melakukan kerjasama dengan Warga Kampung Parigi Rt.003/005 kelurahan Parigi Kecamatan Pondok Aren Tangerang Selatan. Dari hasil survey dan wawancara melalui Warga Kampung Parigi Rt.003/005 bahwa permasalahan yang ada sekarang ini dan masih berlanjut salah satunya yaitu para pelaku UMKM utamanya pedagang kecil yang berada di daerah perkampungan pondok aren tidak mendapatkan penghasilan, dikarenakan tidak bisa keluar rumah untuk menjual barang dagangannya secara langsung kepada para konsumen.

\subsection{Rumusan Masalah}

Dengan mempertimbangkan latar belakang masalah di atas kami berinisiatif untuk membentuk pengabdian masyarakat bagi warga Kelurahan Parigi RT.003/005 Kecamatan Pondok Aren, Kota Tangerang Selatan berupa pelatihan dasar mengenai online marketplace sehingga mereka bisa memanfaatkan teknologi untuk meningkatkan penjualan produknya. Selain itu diberikan juga bantuan berupa pangan (sembako) untuk para pedagang kecil tersebut.

\subsection{Tujuan Pengabdian kepada} Masyarakat

1. Memberi wawasan kepada masyarakat RT 003/005 Kelurahan Parigi Kecamatan Pondok Aren, Kota Tangerang Selatan tentang pemanfaatan online marketplace untuk meningkatkan kegiatan UMKM.

2. Memberi wawasan dan motivasi kepada masyarakat RT 003/005 Kelurahan Parigi Kecamatan Pondok Aren, Kota Tangerang Selatan agar bisa mendapatkan penghasilan, mencukupi kebutuhannya dan tetap bertahan disaat krisis Covid-19.

3. Memberikan bantuan pangan (sembako) kepada masyarakat RT 003/005 Kelurahan Parigi Kecamatan Pondok Aren, Kota Tangerang Selatan

\subsection{Manfaat Pengabdian kepada Masyarakat \\ Setelah mengetahui strategi dan}




\section{Loyalitas Kreativitas \\ Aldi Masyarakat Kreatif}

P-ISSN 2722-2101, E-ISSN 2722-4201

Program Studi Ekonomi Manajemen Universitas Pamulang Jurnal LOKABMAS Kreatif Vol. 01, No. 03, Hal. 44-52

Email:jurnalkreatif.manajemen@gmail.com menerima pelatihan dasar mengenai online marketplace diharapkan masyarakat RT 003/005 Kelurahan Parigi Kecamatan Pondok Aren, Kota Tangerang Selatan mampu mengembangkan UMKM di daerahnya dengan pemanfaatan online marketplace dengan caracara, metode dan inovasi yang lebih kreatif dan menarik.

\section{TINJAUAN PUSTAKA}

\subsection{Kewirausahaan}

Kewirausahaan merupakan kecakapan hidup yang penting dimiliki oleh setiap orang. Kewirausahaan dapat dipelajari dan dikuasai. Orang yang memiliki semangat kewirausahaan disebut wirausaha atau lebih dikenal oleh masyarakat sebagai pengusaha. Wirausaha akan muncul dan berkembang bila ada peluang dan tantangan dalam bidang ekonomi.

Kewirausahaan merupakan sumber daya ekonomi, selain modal, tenaga kerja dan tanah atau lahan. Wirausahalah yang mengupayakan agar modal, tenaga kerja, dan tanah dapat menghasilkan barang dan jasa yang dibutuhkan masyarakat, sehingga memperoleh keuntungan atas usahanya tersebut.

Dalam konteks kewirausahaan, terdapat dua terminologi yang berbeda secara konsep namun memiliki kesamaan dalam praktik. Kedua terminologi tersebut adalah enterpreneurship dan intrapreneurship. Enterprenuership dapat diartikan sebagai kemampuan mengelola usaha sendiri (menjadi bos/atasan untuk dirinya sendiri), sementara intrapreneurship diartikan sebagai kemampuan menerapkan konsep wirausaha dalam mengelola usaha milik orang lain (memiliki bos/atasan yang bukan dirinya sendiri). Adapun pengertian wirausaha menurut para ahli adalah sebagai berikut (Fadiati \& Purwana, 2011).

Suryana (2013) mengemukakan bahwa kewirausahaan (entrepreneurship) adalah suatu disiplin ilmu yang mempelajari tentang nilai, kemampuan (ability), dan perilaku seseorang dalam menghadapi tantangan hidup dan cara memperoleh peluang dengan berbagai resiko yang mungkin dihadapinya. Kewirausahaan merupakan suatu disiplin ilmu tersendiri, memiliki proses sistematis, dan dapat diterapkan dalam bentuk penerapan kreativitas dan keinovasian. Hal tersebut juga diutarakan oleh Yuldinawati dkk. (2018), bukan hanya mengenai kreativitas dan inovasi, percepatan kewirausahaan juga membutuhkan inkubasi bisnis yang efektif.

\subsection{Usaha Mikro, Kecil dan Menengah (UMKM)}

Usaha Kecil Menengah (UKM) mempunyai peran penting dan strategis bagi pertumbuhan ekonomi negara, baik negara berkembang maupun negara maju. Pada saat krisis ekonomi berlangsung di Indonesia, kemampuan UKM untuk tetap bertahan di masa krisis ekonomi adalah bukti bahwa sektor UKM merupakan bagian dari sektor usaha yang cukup tangguh (Ling, 2013).

Pada Bab I pasal 1 UU No 20 Tahun 2008 tentang Usaha Mikro, Kecil, dan Menengah (UMKM), yang dimaksud dengan Usaha Mikro, Kecil, dan Menengah adalah:

1) Usaha Mikro adalah usaha produktif milik orang perorangan dan/atau badan usaha perorangan yang memenuhi kriteria Usaha Mikro sebagaimana diatur dalam UndangUndang ini.

2) Usaha Kecil adalah usaha ekonomi produktif yang berdiri sendiri, yang dilakukan oleh orang perorangan atau badan usaha yang bukan merupakan anak perusahaan atau bukan cabang perusahaan yang dimiliki, dikuasai, atau menjadi bagian baik langsung maupun tidak langsung dari Usaha Menengah atau Usaha Besar yang memenuhi kriteria Usaha Kecil sebagaimana dimaksud dalam UndangUndang ini.

3) Usaha Menengah adalah usaha ekonomi produktif yang berdiri sendiri, yang dilakukan oleh orang perorangan atau badan usaha yang bukan merupakan anak perusahaan atau cabang perusahaan yang dimiliki, dikuasai, atau menjadi bagian baik langsung maupun tidak langsung dengan Usaha Kecil atau Usaha Besar dengan jumlah kekayaan bersih atau hasil penjualan tahunan.

Sedangkan pada Bab IV Pasal 6 UU No 20 Tahun 2008 menyebutkan mengenai batasan atau kriteria dari Usaha Mikro, Kecil, dan Menengah adalah :

(1) Kriteria Usaha Mikro adalah sebagai berikut:

a. memiliki kekayaan bersih paling banyak Rp50.000.000,00 (lima puluh juta rupiah) tidak termasuk tanah dan 


\section{Loyalitas Kreativitas \\ Aldi Masyarakat Kreatif}

P-ISSN 2722-2101, E-ISSN 2722-4201

Program Studi Ekonomi Manajemen Universitas Pamulang Jurnal LOKABMAS Kreatif Vol. 01, No. 03, Hal. 44-52

Email:jurnalkreatif.manajemen@gmail.com bangunan tempat usaha; atau

b. memiliki hasil penjualan tahunan paling banyak Rp300.000.000,00 (tiga ratus juta rupiah).

(2) Kriteria Usaha Kecil adalah sebagai berikut:

a. memiliki kekayaan bersih lebih dari Rp50.000.000,00 (lima puluh juta rupiah) sampai dengan paling banyak Rp500.000.000,00 (lima ratus juta rupiah) tidak termasuk tanah dan bangunan tempat usaha; atau

b. memiliki hasil penjualan tahunan lebih dari Rp300.000.000,00 (tiga ratus juta rupiah) sampai dengan paling banyak Rp2.500.000.000,00 (dua milyar lima ratus juta rupiah).

(3) Kriteria Usaha Menengah adalah sebagai berikut:

a. memiliki kekayaan bersih lebih dari Rp500.000.000,00 (lima ratus juta rupiah) sampai dengan paling banyak Rp10.000.000.000,00 (sepuluh milyar rupiah) tidak termasuk tanah dan bangunan tempat usaha; atau

b. memiliki hasil penjualan tahunan lebih dari Rp2.500.000.000,00 (dua milyar lima ratus juta rupiah) sampai dengan paling banyak Rp50.000.000.000,00 (lima puluh milyar rupiah).

Menurut data Badan Pusat Statistik (BPS), kontribusi UMKM terhadap Produk Domestik Bruto (PDB) Indonesia mencapai 61,41 persen pada tahun 2018. Tentu kontribusi ini menunjukkan peran UMKM sebagai tulang punggung ekonomi nasional Indonesia ( Pakpahan, 2020)

Kemenkop dan UKM memperkirakan ada sekitar 37.000 UMKM yang memberikan laporan bahwa mereka terdampak sangat serius dengan adanya pandemi ini ditandai dengan: sekitar 56 persen melaporkan terjadi penurunan penjualan, 22 persen melaporkan permasalahan pada aspek pembiayaan, 15 persen melaporkan pada masalah distribusi barang, dan 4 persen melaporkan kesulitan mendapatkan bahan baku mentah.6 Masalah-masalah diatas juga semakin meluas jika dikaitkan dengan adanya kebijakan Pembatasan Sosial Berskala Besar (PSBB) yang diterapkan di beberapa wilayah di Indonesia. Merujuk pada Peraturan Menteri Kesehatan No. 9/2020 tentang Pedoman PSBB dalam rangka Percepatan Penanganan COVID19.

IMF meramalkan Indonesia masih akan mengalami pertumbuhan ekonomi positif sebesar 0,5 persen dari target awal 5 persen di 2020 sementara Menteri Keuangan Sri Mulyani memprediksi pertumbuhan ekonomi Indonesia ada di kisaran 0,3-2.8 persen di tahun 2020.10 Angka-angka tersebut, baik jumlah UMKM dan kontribusinya serta prediksi pertumbuhan ekonomi global dan Indonesia, perlu mendapatkan perhatian serius dan dijadikan bahan evaluasi pemerintah untuk merancang kebijakan dan strategi yang tepat.

\section{MATERI DAN METODE PELAKSANAAN}

\subsection{Kerangka Pemecahan Masalah}

Alternatif pemecahan masalah dilakukan dengan memberikan bantuan berupa pelatihan untuk kewirausahaan melalui online marketplace kepada warga RT 003/005 Kelurahan Parigi Kecamatan Pondok Aren Tangerang Selatan sehingga mereka bisa bertahan menghadapi krisis akibat pandemi COVID-19 serta bantuan berupa pangan (sembako) untuk para pelaku UMKM tersebut.

Beberapa masalah utama yang dihadapi oleh UKM antara lain kurangnya permodalan, sumber daya manusia (SDM) yang terbatas, lemahnya jaringan usaha dan kemampuan penetrasi pasar, pemasaran produk, iklim usaha, terbatasnya sarana dan prasarana, sifat produk yang ditawarkan, terbatasnya akses pasar dan lain-lain.

Solusinya yaitu dengan beberapa strategi yang bisa dicoba untuk mengubah usaha konvensional yang masih mengandalkan cara lama dalam memulai usaha, untuk bisa beradaptasi dengan perkembangan dunia usaha di situasi industri 4.0 saat ini antara lain (jurnal.id, 2019).

\section{1) Memanfaatkan Teknologi}

Melakukan kegiatan pemasaran dengan memanfaatkan internet atau dapat membuat pembukuan dengan menggunakan komputer dan masih 


\section{Loyalitas Kreativitas \\ Aldi Masyarakat Kreatif}

P-ISSN 2722-2101, E-ISSN 2722-4201

Program Studi Ekonomi Manajemen Universitas Pamulang Jurnal LOKABMAS Kreatif Vol. 01, No. 03, Hal. 44-52

Email:jurnalkreatif.manajemen@gmail.com banyak lagi yang lainnya.

2) Gunakan sosial media

Indonesia memiliki banyak pengguna sosial media seperti Twitter, Instagram, Facebook, BBM, Line dan sebagainya. Karena itu sosial media dapat dijadikan alat dalam strategi bisnis.

3) Menggunakan digital marketing

Digital marketing adalah aktivitas promosi sebuah brand atau pun produk/jasa menggunakan media elektronik atau digital. Adapun teknik pemasaran dalam digital marketing seperti seacrh engine optimization (SEO), billboard elektronik, iklan televisi dan radio, email marketing dan lainnya.

4) Mobile friendly

Tingginya jumlah pengguna smarthpone dan produk gadget lainnya juga perlu diperhatikan. Perlu menyesuaikan strategi pemasaran dengan tampilan yang mobile friendly. Sehingga akan lebih banyak orang yang melihat toko online Anda.

5) Menggunakan aplikasi

Dengan menggunakan aplikasi bisa menghemat biaya, waktu dan juga tenaga. Selain itu, aplikasi-aplikasi tersebut juga memberikan kenyamanan dalam penggunaannya.

6) Inovasi

Seperti yang diketahui bahwa dunia bisnis sangat cepat berubah, hampir setiap harinya ada saja sebuah trend baru. Oleh karena itu, inovasi sangatlah dibutuhkan agar dapat bersaing dengan kompetitor Anda. Buatlah produk atau jasa Anda berbeda dan istimewa dari yang lain, melalui proses yang baik dan benar.

7) Memberikan pelayanan terbaik

Tidak ada yang lebih berharga dalam dunia bisnis dibandingkan dengan memenuhi kebutuhan konsumen. Meskipun, dalam dunia digital Anda juga harus memberikan pelayanan terbaik kepada konsumen Anda.

\subsection{Realisasi Pemecahan Masalah}

Persiapan Kegiatan Pengabdian pada Masyarakat. Sebelum kegiatan dilaksanakan, maka dilakukan persiapan- persiapan sebagai berikut:

1. Melakukan studi pustaka tentang online marketplace sehingga diharapkan setelah pelatihan kepada masyarakat RT 003/005 Kelurahan Parigi Kecamatan Pondok Aren, Kota Tangerang Selatan, mereka mampu mengembangkan UMKM di daerahnya dengan pemanfaatan online marketplace dengan cara- cara, metode dan inovasi yang lebih kreatif dan menarik.

2. Melakukan persiapan bahan- bahan untuk pemberian materi terkait pemanfaatan online marketplace serta bahan sembako yang akan dibagikan kepada warga RT 003/005 Kelurahan Parigi Kecamatan Pondok Aren, Kota Tangerang Selatan.

3. Menentukan waktu pelaksanaan dan lamanya kegiatan pengabdian bersamasama tim pelaksana.

4. Menentukan dan mempersiapkan materi yang akan disampaikan dalam kegiatan pengabdian masyarakat.

\subsection{Khalayak Sasaran}

Khalayak sasaran yang dipilih adalah warga RT 003/005 Kelurahan Parigi Kecamatan Pondok Aren, Kota Tangerang Selatan terutama para pelaku UMKM sebanyak 40 orang.

\subsection{Tempat dan Waktu Pelaksanaan}

Tempat pelaksanaan kegiatan Pengabdian Kepada Masyarakat yang kami lakukan di RT 003/005 Kelurahan Parigi Kecamatan Pondok Aren, Kota Tangerang Selatan. Adapun waktu pelaksanaan adalah dari tanggal 17-19 Mei 2020.

\subsection{Metode Pelaksanaan}

Metode Pelaksanaan program 


\section{Loyalitas Kreativitas \\ Aldi Masyarakat Kreatif}

P-ISSN 2722-2101, E-ISSN 2722-4201

Program Studi Ekonomi Manajemen Universitas Pamulang Jurnal LOKABMAS Kreatif Vol. 01, No. 03, Hal. 44-52

Email:jurnalkreatif.manajemen@gmail.com
Pengabdian Kepada Masyarakat ini adalah melalui kegiatan penyuluhan dan pelatihan mengenai online marketplace serta bantuan langsung berupa sembako kepada masyarakat RT 003/005 Kelurahan Parigi Kecamatan Pondok Aren, Kota Tangerang Selatan.

Adapun tahapan-tahapan yang kami lakukan dalam Pengabdian Kepada Masyarakat ini diantaranya sebagai berikut: Tahap Persiapan:

- Survey Awal

Kami melakukan survey kepada Warga RT 003/005 Kelurahan Parigi Kecamatan Pondok Aren, Kota Tangerang Selatan yang menggalang dana untuk para pelaku UMKM yang membutuhkan. Setelah kami mendapatkan data masyarakat di perkampungan yang membutuhkan bantuan dikarenakan tidak mendapatkan penghasilan. Hal ini disebabkan karena tidak boleh melakukan kegiatan di luar rumah.

- Pemantapan dan penentuan lokasi dan sasaran.

Setelah survey dilakukan maka ditentukan lokasi pelaksanaan dan sasaran yang benar-benar membutuhkan bantuan. Adapun data yang kami dapatkan dari beberapa daerah di Pondok Aren kami telaah dan kami distribusikan ke orang-orang yang benar-benar membutuhkan bantuan.

Tahap Pelaksanaan :

Tahap ini kami memberikan donasi kepada Warga Warga RT 003/005 Kelurahan Parigi Kecamatan Pondok Aren, Kota Tangerang Selatan untuk didistribusikan kepada para pelaku UMKM terutama pedagang kecil dan pedagang keliling yang paling terkena dampak Covid-19 dan bantuan tersebut dibelikan sembako untuk segera didistribusikan kepada yang membutuhkan.

Selain itu, kami beserta warga RT 003/005 Kelurahan Parigi Kecamatan Pondok Aren, Kota Tangerang Selatan juga membantu dalam menggiatkan UKM dengan memberikan pelatihan peningkatan UMKM yang ada disekitar mereka. Sehingga ada pengalaman yang baru dan juga pemasukan yang lebih baik sehingga mereka akan lebih sejahtera.

Tahap Pelatihan

Untuk melaksanakan kegiatan tersebut digunakan beberapa metode pelatihan yaitu:
a. Metode ceramah
b. Metode tanya jawab
c. Metode simula

\section{HASIL DAN PEMBAHASAN 4.1 Hasil Kegiatan Pelatihan}

Dari hasil wawancara, tanya jawab dan pengamatan langsung selama kegiatan berlangsung, kegiatan pengabdian kepada masyarakat ini memberikan hasil :

1. Memberi wawasan kepada masyarakat RT 003/005 Kelurahan Parigi Kecamatan Pondok Aren, Kota Tangerang Selatan tentang pemanfaatan online marketplace untuk meningkatkan kegiatan UMKM.

2. Memberi wawasan dan motivasi kepada masyarakat RT 003/005 Kelurahan Parigi Kecamatan Pondok Aren, Kota Tangerang Selatan agar bisa mendapatkan penghasilan, mencukupi kebutuhannya dan tetap bertahan disaat krisis Covid-19.

3. Memberikan bantuan pangan (sembako) kepada masyarakat RT 003/005 Kelurahan Parigi Kecamatan Pondok Aren, Kota Tangerang Selatan.

\subsection{Faktor Pendukung dan Faktor Penghambat}

Beberapa faktor yang mendukung terlaksananya kegiatan pengabdian kepada masyarakat ini adalah besarnya minat dan antusiasme peserta selama kegiatan. Sehingga kegiatan bisa berlangsung dengan 


\section{Loyalitas Kreativitas \\ Aldi Masyarakat Kreatif}

P-ISSN 2722-2101, E-ISSN 2722-4201

Program Studi Ekonomi Manajemen Universitas Pamulang Jurnal LOKABMAS Kreatif Vol. 01, No. 03, Hal. 44-52

Email:jurnalkreatif.manajemen@gmail.com lancar dan efektif. Sedangkan faktor penghambatnya adalah keterbatasan waktu pelatihan dan fasilitas peralatan yang masih minim.

\section{KESIMPULAN DAN SARAN 5.1 Kesimpulan}

1. Wawasan masyarakat RT 003/005 Kelurahan Parigi Kecamatan Pondok Aren, Kota Tangerang Selatan tentang pemanfaatan online marketplace untuk meningkatkan kegiatan UMKM semakin meningkat.

2. Wawasan dan motivasi masyarakat RT 003/005 Kelurahan Parigi Kecamatan Pondok Aren, Kota Tangerang Selatan agar bisa mendapatkan penghasilan, mencukupi kebutuhannya dan tetap bertahan disaat krisis Covid-19 semakin meningkat.

3. Bantuan pangan (sembako) bagi masyarakat RT 003/005 Kelurahan Parigi Kecamatan Pondok Aren, Kota Tangerang Selatan bisa digunakan untuk memenuhi kebutuhan hidupnya dalam jangka pendek.

\subsection{Saran}

Mengingat besarnya manfaat kegiatan pengabdian kepada masyarakat ini, maka untuk selanjutnya perlu adanya :

1. Mengadakan sosialisasi, pelatihan dan bantuan serupa untuk masyarakat di daerah- daerah yang lain.

2. Adanya kesinambungan program pasca kegiatan pengabdian ini sehingga masyarakat mampu mengaplikasikan wawasan dan pengetahuannya mengenai online marketplace dalam tindakan nyata.

\section{DAFTAR PUSTAKA}

Elburdah, R. P., \& Oktrima, B. (2020). PENGARUH COMMUNITY OF PRACTICE PADA IMPLEMENTASI KNOWLEDGE

\section{MANAGEMENT PADA KANTOR KELURAHAN REMPOA. JURNAL LOKABMAS KREATIF, 1(2), 11-15.}

Fadiati, A., \& Purwana, D. (2011). Menjadi Wirausaha Sukses. Bandung: PT Remaja Rosdakarya.

jurnal.id. (2019, Maret 12). Retrieved from https://www.jurnal.id: https://www.jurnal.id/id/blog/strategibisnis-untuk-bersaing-di-era-digital/

Ling, A. (2013). Pengelolaan dan Pengembangan Usaha pada Usaha Mikro Kecil Menengah (Studi Deksriptif pada Rumah Makan Palem Asri Surabaya). AGORA Vol. 1., No. 1, $1-8$.

Pakpahan, Aknolt Kristian. (2020). Covid-19 dan Implikasi bagi Usaha Mikro Kecil dan Menengah. Jurnal Ilmiah Hubungan Internasional-Pacis. Edisi Khusus April 2020

Pasaribu, V. L. D., Susanti, F., \& Hartuti, E. T. K. (2019). Memotivasi Siswa dan Siswi SMK Letris Indonesia di Dalam Menentukan Pilihan Untuk Melanjutkan Pendidikan Atau Bekerja Setelah Lulus Sekolah. Jurnal Pengabdian Dharma Laksana, 1(2), 161-172.

Pasaribu, V. L. D., Elburdah, R. P., Sudarso, E., \& Fauziah, G. (2020). PENGGUNAAN MANAJEMEN WAKTU TERHADAP PENINGKATAN PRESTASI BELAJAR DI SMP ARAISIYAH. Jurnal ABDIMAS Tri Dharma Manajemen, 1(1).

Pasaribu, V. L. D., Agrasadya, A., Shabrina, N., \& Krisnaldy, K. (2020). MENJADI ENTERPRENEUR MUDA YANG MEMILIKI JIWA LEADERSHIP UNTUK MENGHADAPI MASA DEPAN. Abdi Laksana, 1(1).

Pasaribu, V. L. D., Sulaiman, S., Sutiman, S., Thaharudin, T., \& Purnomo, B. Y. (2020). PENGENALAN LETAK POSYANDU TERDEKAT DIKELURAHAN PISANGAN DENGAN MANAJEMEN PEMASARAN REVOLUSI 4.0 UNTUK MENINGKATKAN PENGETAHUAN MASYARAKAT LETAK 
Loyalitas Kreativitas
Aldi Masyarakat Kreatif
P-ISSN 2722-2101, E-ISSN 2722-4201

Program Studi Ekonomi Manajemen Universitas Pamulang Jurnal LOKABMAS Kreatif Vol. 01, No. 03, Hal. 44-52

Email:jurnalkreatif.manajemen@gmail.com
DAN FUNGSI POSYANDU TERDEKAT PADA KELURAHAN

PISANGAN. DEDIKASI PKM, 1(1), 105-110.

Priadi, A., Pasaribu, V. L. D., Virby, S., Sairin, S., \& Wardani, W. G. (2020). PENGUATAN EKONOMI KREATIF BERBASIS SUMBER DAYA DESA DIKELURAHAN

REMPOA. Abdi Laksana, 1(3), 356-358.

Suryana, Y. (2013). Kewirausahaan, Pedoman Praktis, Kiat Dan Proses Menuju Sukses. Jakarta: SALEMBA EMPAT.

Yuldinawati, L., Tricahyono, D., Anggadwita, G., \& Alamanda, D. T. (2018). Towards a Framework for ICT-Based Entrepreneurship Development through Business Incubation Processes: Case Study of a Techno Park. International Journal of Business and Globalisation , 21(1). Retrieved from goo.gl/jtreQ4

\section{DOKUMENTASI KEGIATAN}
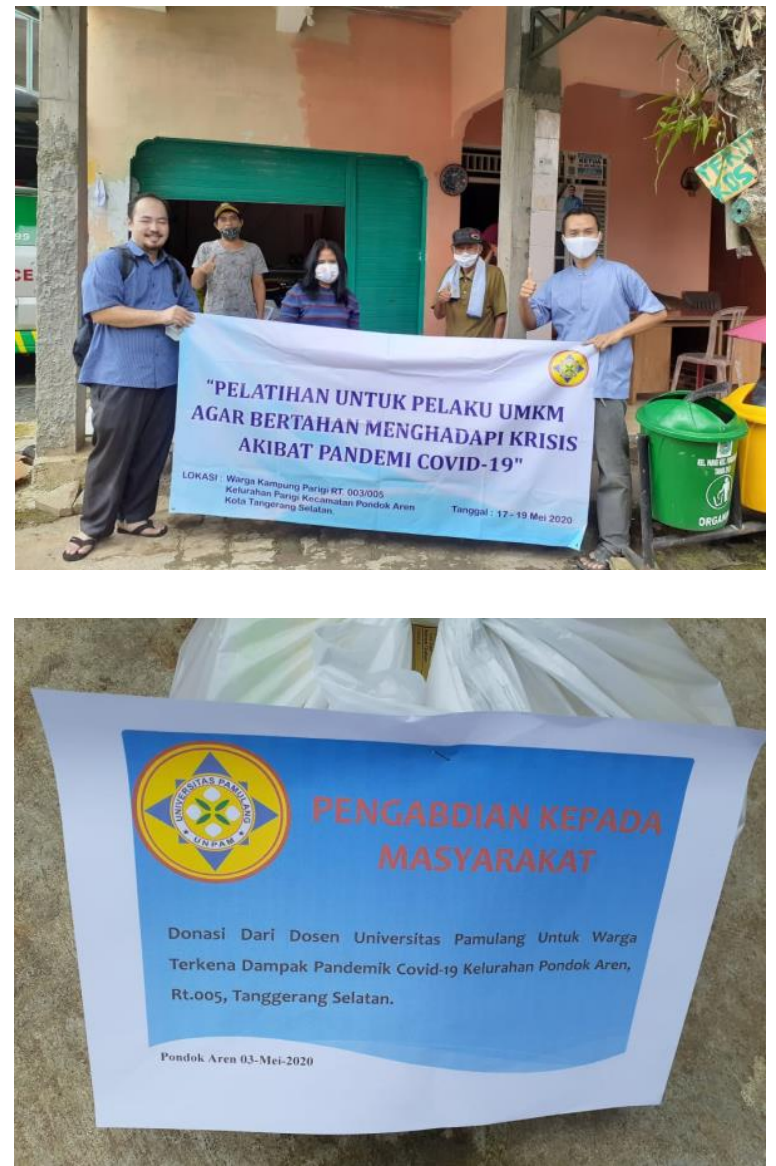
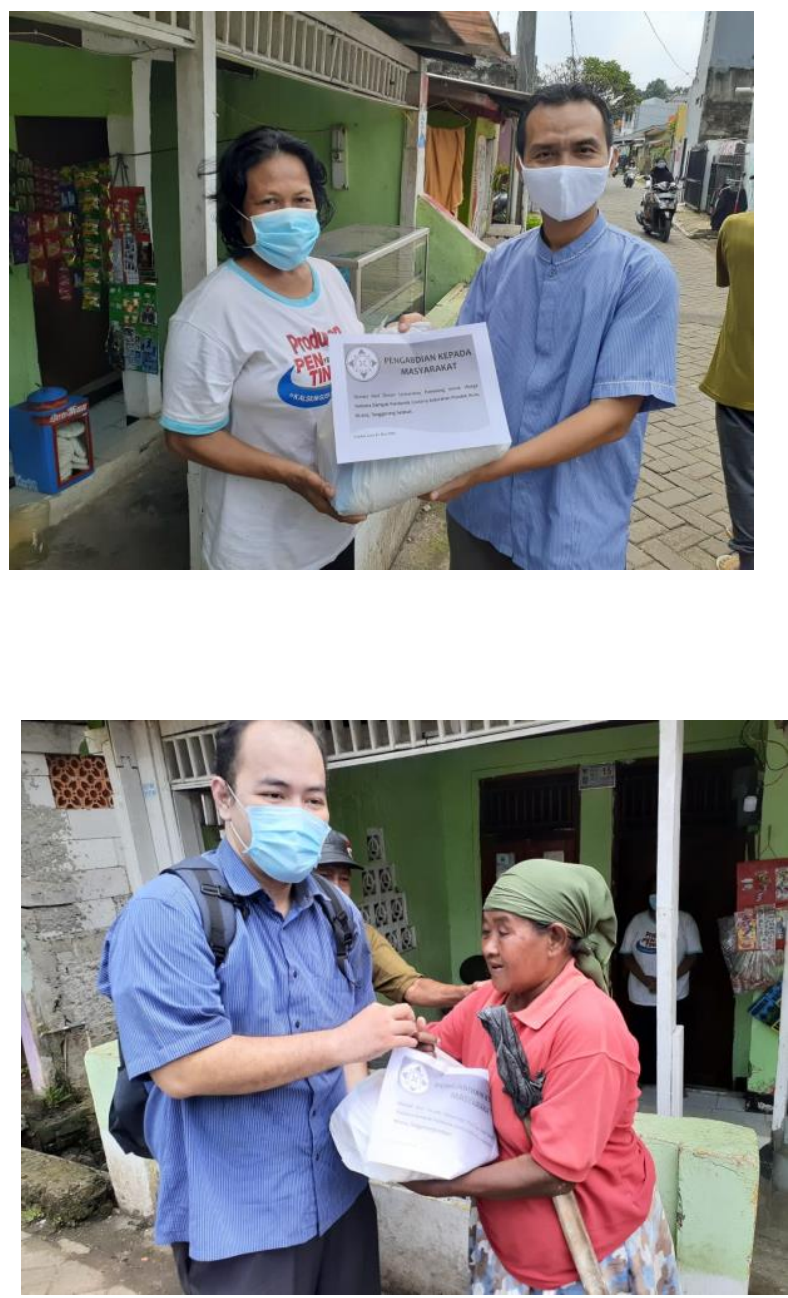